\title{
Pemetaan Tingkat Bahaya Bencana Gempabumi Di Wilayah Banyuwangi Berdasarkan Percepatan Tanah Maksimum
}

\section{Mapping the Level of Earthquake Hazards in Banyuwangi Region Based on Peak Ground Acceleration}

\author{
Muhamad Abdul Ghofur $^{1 *}$, I Ketut Sukarasa ${ }^{1}$, Rudy Darsono ${ }^{2}$ \\ ${ }^{1}$ Program Studi Fisika, Fakultas Matematika dan Ilmu Pengetahuan Alam, Universitas Udayana, \\ Kampus Bukit, Jimbaran, Badung, Bali, Indonesia 80361 \\ ${ }^{2}$ Balai Besar Meteorologi Klimatologi dan Geofisika Wilayah III, Jl. RayaTuban, Badung, Bali, \\ Indonesia 80361 \\ Email: abdulghofur@student.unud.ac.id*; sukarasafisika@gmail.com ; rudy.darsono@bmkg.go.id
}

\begin{abstract}
Abstrak - Wilayah Banyuwangi merupakan daerah rawan bencana gempabumi karena berdekatan dengan zona megathrust (pertemuan lempeng Indo-Australia dan Eurasia) dan back arc. Penelitian ini bertujuan untuk menentukan rumus empiris yang sesuai diterapkan di wilayah Banyuwangi dan menentukan tingkat bahaya bencana gempabumi di wilayah Banyuwangi. Data yang dugunakan yaitu data sekunder alat accelerograph tahun 2017-2020 dan data parameter gempabumi dari International Seismological Center (ISC) tahun 1970-2020. Dalam menentukan nilai percepatan getaran tanah maksimum penelitian ini membandingkan 5 persamaan rumus empiris, yaitu rumus empiris Mc. Guirre R.K (1963), Esteva (1970), Donovan (1973), Setiawan (2012), dan Fukushima \& Tanaka (1990). Hasil penelitian ini menunjukkan rumus empiris Setiawan merupakan rumus paling sesuai untuk diterapkan di wlayah Banyuwangi. Tingkat bahaya bencana gempabumi paling besar berada di wilayah Banyuwangi sebelah timur dalam skala VII-VIII MMI, dengan nilai percepatan getara tanah maksimum tertinggi yaitu 301,801 gal.
\end{abstract}

Kata kunci: Wilayah Banyuwangi, gempabumi, percepatan tanah maksimum, metode empiris, tingkat bahaya gempabumi

\begin{abstract}
Banyuwangi area is an earthquake prone area because it is close to the megathrust zone (indo-Australian and Eurasian plate junction) and back arc. The aim of this research is to determine the most suitable empirical formula for Banyuwangi area and to determine the level of earthquake hazard in Banyuwangi region. The peak ground acceleration value is determined by comparing 5 empirical equations, namely the empirical formula of Mc. Guirre R.K (1963), Esteva (1970), Donovan (1973), Setiawan (2012), and Fukushima \& Tanaka (1990). The results show that the empirical formula Setiawan is the most suitable formula among other empirical formula. The largest earthquake hazard level is in the eastern Banyuwangi region in the scale of VII-VIII MMI, with the highest peak ground acceleration value of 301,801 gal.
\end{abstract}

Keywords: Banyuwangi region, earthquake, peak ground acceleration, empirical method, earthquake hazard level

\section{Pendahuluan}

Gempabumi adalah peristiwa bergetarnya bumi akibat pelepasan energi secara tiba-tiba yang ditandai dengan patahnya lapisan batuan pada kerak. Penyebab terjadinya energi gempabumi dihasilkan dari pergerakan lempeng-lempeng tektonik. Energi yang dihasilkan dipancarkan ke segala arah berupa gelombang gempabumi, sehingga efeknya dapat dirasakan sampai ke permukaan bumi [1]. Indonesia merupakan daerah pertemuan tiga lempeng tektonik yaitu lempeng Pasifik, Indo-Australia, dan Eurasia. Oleh karena itu, keaktifan kegempaan banyak terjadi pada daerah pertemuan antara lempeng-lempeng tersebut. Ketiga lempeng tersebut bergerak satu sama lainnya. Lempeng Indo-Australia bergerak dari selatan ke utara dan lempeng Pasifik bergerak dari timur ke barat [2].

Susunan lempengan wilayah Banyuwangi berdekatan dengan lintasan jalur gempa, yaitu zona megathrust (pertemuan lempeng Indo-Australia dan Eurasia) di Samudera Hindia yang berada di Selatan Banyuwangi. Banyuwangi memiliki garis pantai paling panjang di Jawa Timur yaitu sekitar $175 \mathrm{~km}$. 
Oleh karena itu Banyuwangi memiliki potensi diguncang gempa besar disertai tsunami. Pada tanggal 2 Juni 1994 Banyuwangi pernah dilanda gempabumi dengan magnitudo 7,8 pada koordinat 112,835 BT dan 10,477 LS di Selatan Banyuwangi. Gempabumi tersebut mengakibatkan tsunami yang berdampak 250 korban meningal, 423 korban luka-luka, 27 korban hilang, 1.500 rumah rusak atau hancur dan 278 perahu tenggelam atau rusak [3].

Informasi tentang nilai percepatan tanah maksimum dan pola sebarannya merupakan sesuatu yang penting untuk diketahui dalam perencanaan pembangunan infrasutruktur tahan gempa. Informasi tersebut dapat digunakan sebagai dasar pemetaan lokasi-lokasi yang rawan mengalami kerusakan ketika terjadi gempabumi. Percepatan tanah maksimum dapat diketahui melalui dua cara yaitu pengukuran dengan menggunakan alat accelerograph dan melalui pendekatan empiris. Ada beberapa metode yang bisa dipakai untuk menentukan nilai percepatan tanah maksimum secara empiris yaitu metode Donavan, Esteva, Murphy - O'Brein, Gutenberg - Richter, Kanai, Kawasumi, Mc. Guirre R.K dan lain-lain [4]. Berdasarkan uraian di atas wilayah Banyuwangi merupakan daerah rawan bencana gempa. Oleh karena itu peneliti ingin memetakan tingkat bahaya bencana gempabumi di wilayah Banyuwangi berdasarkan pola percepatan tanah maksimum dengan menggunakan data gempabumi dari tahun 1970-2020.

\section{Landasan Teori}

\subsection{Kabupaten Banyuwangi}

Kabupaten Banyuwangi dengan luas wilayah 5.782,50 km², pada tahun 2018 terdiri atas 25 Kecamatan, 28 Kelurahan dan 189 desa, 87 Lingkungan dan 751 Dusun, 2.839 Rukun Warga (RW) dan 10.569 Rukun Tetangga (RT). Tahun 2018 penduduk Kabupaten Banyuwangi sebanyak 1,735,845 jiwa, terdiri dari 864.124 jiwa perempuan dan 871.721 jiwa laki-laki. Penduduk tersebar di 25 Kecamatan yaitu Kecamatan Pesanggaran, Bangorejo, Purwoharjo, Tegaldlimo, Muncar, Cluring, Gambiran, Srono, Genteng, Glenmore, Kalibaru, Singojuruh, Rogojampi, Kabat, Glagah, Banyuwangi, Giri, Wongsorjo, Songgon, Sempu, Kalipuro, Siliragung, Tegalsari, Licin serta Kecamatan Blimbingsari [5]. Untuk peta wilayah Banyuwangi bisa dilihat pada Gambar 1.

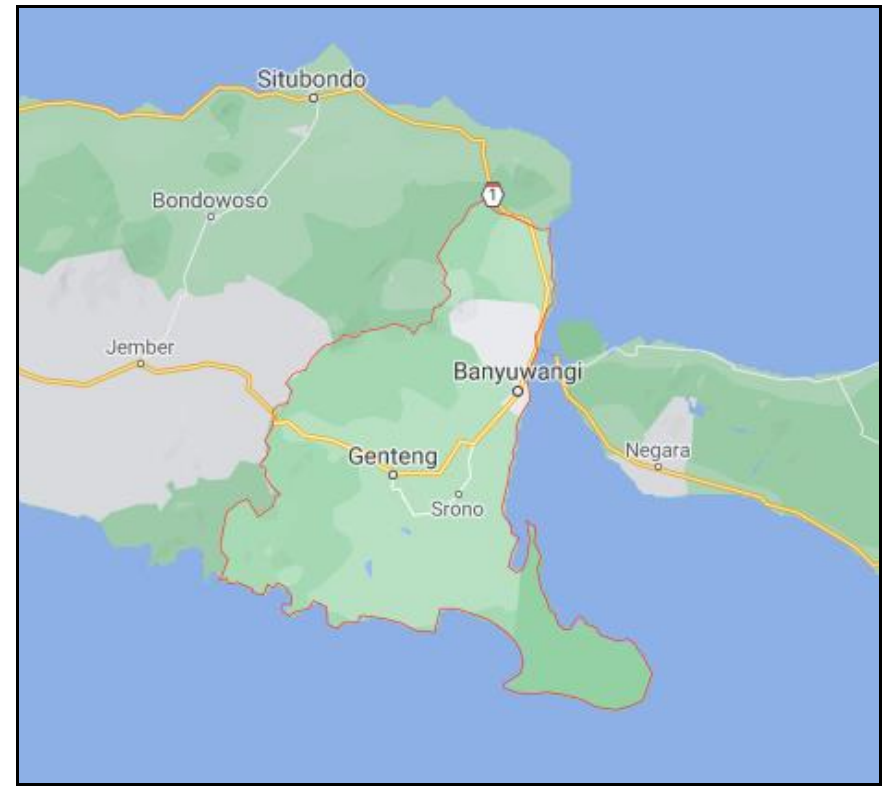

Gambar 1. Peta wilayah Banyuwangi [6].

Secara geografis Kabupaten Banyuwangi terletak pada koordinat $113^{\circ} 53^{\prime}-114^{\circ} 38$ BT dan $7^{\circ} 43^{\prime}-8^{\circ} 46^{\prime}$ LS, terletak di ketinggian 0-2.500 meter di atas permukaan laut. Berdasarkan struktur geologi, luas tanah di Kabupaten Banyuwangi sebagian besar merupakan hasil Gunung Api Kwarter Muda 30\% dan Aluvium 23\% yang berupa tanah liat, halus dan dapat menampung air hujan sehingga cocok untuk dimanfaatkan sebagai lahan pertanian. Struktur geologi lainnya adalah miosen falses semen $16 \%$, miosen falses batu gamping 13\%, hasil gunung api kwarter tua dengan luas 10\% dan struktur geologi Andesit 
merupakan struktur geologi terendah di Kabupaten Banyuwangi dengan luas hanya sebesar $8 \%$. Adapun keadaan jenis tanah di Kabupaten Banyuwangi terdiri dari regosol, litosol, latosol, podsolik dan gambut [5].

\subsection{Parameter gempabumi}

Menurut Ibrahim dan Subardjo [7] parameter gempabumi biasanya digambarkan dengan waktu kejadian gempa, kedalaman sumber gempa, hiposenter dan episenter, magnitudo, dan intensitas gempabumi.

a. Waktu Kejadian Gempa (Origin Time)

Waktu kejadian gempa (Origin Time) adalah waktu terlepasnya akumulasi tegangan (stress) yang berbentuk penjalaran gelombang gempabumi dan dinyatakan dalam hari, tanggal, bulan, tahun, jam, menit, detik dalam satuan WIB atau UTC (Universal Time Coordinated).

b. Kedalaman Sumber Gempa

Kedalaman sumber gempa merupakan ukuran kedalaman pusat terjadinya suatu gempa. Kedalaman sumber gempa bervariasi mulai dari dangkal, menengah, dan dalam yang batasan nilainya tergantung dari kondisi tektonik setempat.

c. Hiposenter dan Episenter

Hiposenter merupakan pusat gempabumi dibawah permukaan bumi, sedangkan episenter merupakan titik dipermukaan bumi. Lokasi hiposenter ditunjukkan dengan kedalaman, sedangkan lokasi episenter ditunjukkan dengan titik koordinat dipermukaan bumi. Jika hiposenter menyatakan jarak titik pusat gempa dibawah permukaan bumi ke stasiun pengamatan dan jarak episenter menyatakan jarak titik episenter kestasiun pengamatan.

d. Magnitudo

Magnitudo gempa adalah ukuran kekuatan gempabumi yang menggambarkan besarnya energi yang terlepas pada saat gempabumi terjadi dan merupakan hasil pengamatan seismograf. Satuan yang umum digunakan di Indonesia adalah skala Richter (Richter Scale), yang bersifat logaritmik.

e. Intensitas

Yaitu skala dampak kerusakan yang dialami di permukaan bumi akibat gempabumi, biasanya dinyatakan dalam skala MMI (Modified Mercally Intencity).

\subsection{Percepatan getaran tanah maksimum (PGA)}

Percepatan getaran tanah maksimum atau Peak Ground Acceleration (PGA) adalah nilai percepatan getaran tanah terbesar yang pernah terjadi di suatu tempat yang diakibatkan oleh gelombang gempabumi. Percepatan getaran tanah maksimum yang terjadi pada suatu titik tertentu dalam suatu kawasan dihitung dari semua gempabumi yang terjadi pada kurun waktu tertentu dengan memperhatikan besar magnitudo dan jarak hiposenternya, serta periode predominan tanah dimana titik tersebut berada [8]. Percepatan tanah maksimum merupakan salah satu parameter peting yang digunakan untuk meninjau kerusakan tanah yang terjadi di permukaan bumi akibat dari gempabumi. Dengan mengetahui nilai dari percepatan tanah disuatu daerah, maka akan dapat diketahui wilayah yang rawan kerusakan akibat dari gempabumi. Besar nilai perepatan tanah dapat diukur dengan menggunakan sensor accelerograph [9].

Pengukuran percepatan tanah dengan menggunakan rumus empiris dapat dilakukan dengan pendekatan dari beberapa rumus yang diturunkan dari magnitudo gempa atau data intensitas. Perumusan ini tidak selalu benar, bahkan dari suatu metode ke metode lainnya tidak selalu sama, namun cukup memberikan gambaran umum tentang percepatan tanah maksimum atau Peak Ground Acceleration (PGA) [10]. Faktor-faktor yang mempengaruhi besar kecilnya nilai percepatan tanah pada suatu tempat antara lain magnitudo gempa, kedalaman hiposenter, jarak episenter, dan kondisi tanah. Ada beberapa metode yang bisa dipakai untuk menentukan nilai percepatan tanah maksimum secara empiris antara lain metode Donavan, Esteva, Setiawan, Fukushima dan Tanaka, Mc. Guirre R.K dan lain-lain. Metodemetode empiris tersebut ditentukan berdasarkan suatu kasus gempabumi pada suatu tempat tertentu, dengan memperhitungkan karakteristik sumber gempabuminya, kondisi geologi dan geotekniknya [11]. Berikut adalah beberapa rumus empiris yang digunakan dalam penelitian yaitu:

1) Rumus empiris Mc. Guirre R.K. (1963)

Rumusan ini berdasarkan gempabumi di California Selatan yang berada pada sepanjang patahan San Andreas. Persamaan empiris metode Mc. Guirre R.K (1963) yang ditulis pada Persamaan (1). 


$$
a=\frac{472,3 \times 10^{0,278 M s}}{(R+25)^{1,301}}
$$

2) Rumus empiris Esteva (1970)

Berdasarkan gempa California yang telah dikoreksi dan dievaluasi secara statistik, Esteva memperoleh model empiris percepatan getaran tanah seperti yang ditulis pada Persamaan (2).

$$
a=\frac{5600 \times \operatorname{Exp}(0,5 M s)}{(R+40)^{2}}
$$

3) Rumus empiris Donovan (1973)

Dengan menggunakan nilai rata-rata percepatan getaran tanah dari gempabumi yang terjadi di Amerika Barat, Jepang dan Papua New Guinea, Donovan memperoleh suatu model empiris Percepatan getaran tanah yang ditulis pada Persamaan (3).

$$
a=\frac{1080 \times \operatorname{Exp}(0,5 M s)}{(R+25)^{1,32}}
$$

4) Rumus Setiawan (2012)

Rumus ini merupakan adaptasi dari rumusan Lin dan Wu (2010) yang diterapkan di wilayah Bali dan sekitarnya. Persamaan empiris metode Setiawan (2012) ditulisan pada Persamaan (4).

$$
\log _{10} a=(-2,0663) \log _{10}(R)+(0,9019) M b+0,1091
$$

5) Rumus Fukushima dan Tanaka (1990)

Rumus ini diterapkan di wilayah Jepang yang ditulis pada Persamaan (5).

$$
\log _{10} a=0,41 M s-\log _{10}\left(R+0,032 * 10^{0,4 M s}\right)-0,0034 R+1,3
$$

Dengan, $R=\sqrt{\Delta^{2}+h^{2}}$

$\mathrm{a}=$ percepatan tanah di permukaan (gal), $\mathrm{Ms}=$ magnitudo gelombang permukaan $(\mathrm{SR}), \mathrm{Mb}=$ magnitudo gelombang body $(\mathrm{SR}), \mathrm{R}=$ Jarak hiposenter $(\mathrm{km}), \Delta=$ jarak episenter $(\mathrm{km})$, dan $\mathrm{h}=$ kedalaman sumber gempa $(\mathrm{km})$.

Untuk menentukan jarak episenter dari titik pengamatan digunakan Persamaan (7) [12].

$$
\Delta=\cos ^{-1}\left[\sin \theta_{E} \sin \theta_{S}+\cos \theta_{E} \cos \theta_{S} \cos \left(\phi_{E}-\phi_{S}\right)\right] \times r
$$

Dengan $\Delta=$ jarak episenter, $\theta_{E}=$ lintang posisi episenter, $\theta_{S}=$ lintang stasiun pengamatan, $\phi_{S}=$ bujur stasiun pengamatan, $\phi_{E}=$ bujur posisi episenter, dan $r=$ jari-jari bumi yaitu $6371 \mathrm{~km}$.

\subsection{Skala intensitas gempabumi}

SIG adalah skala intensitas gempabumi. Skala ini menyatakan dampak yang ditimbulkan akibat terjadinya gempabumi. Skala Intensitas Gempabumi (SIG-BMKG) digagas dan disusun dengan mengakomodir keterangan dampak gempabumi berdasarkan tipikal budaya atau bangunan di Indonesia. Skala ini disusun lebih sederhana dengan hanya memiliki lima tingkatan yaitu I-V. SIG-BMKG diharapkan bermanfaat untuk digunakan dalam penyampaian informasi terkait mitigasi gempabumi dan atau respon cepat pada kejadian gempabumi merusak. Skala ini dapat memberikan kemudahan kepada masyarakat untuk dapat memahami tingkatan dampak yang terjadi akibat gempabumi dengan lebih baik dan akurat. Table skala intensitas gempabumi BMKG dapat dilihat pada Table 1 [1].

MMI (Modified Mercalli Intensity) adalah satuan untuk mengukur kekuatan gempabumi. Satuan ini diciptakan oleh seorang vulkanologis dari Italia yang bernama Giuseppe Mercalli pada tahun 1902. Skala Mercalli terbagi menjadi 12 pecahan berdasarkan informasi dari orang-orang yang selamat dari gempa tersebut dan juga dengan melihat serta membandingkan tingkat kerusakan akibat gempabumi tersebut. Oleh itu skala Mercalli adalah sangat subjektif dan kurang tepat dibanding dengan perhitungan magnitudo gempa yang lain. Oleh karena itu, saat ini penggunaan Skala Richter lebih luas digunakan untuk untuk mengukur kekuatan gempabumi. Tetapi skala Mercalli yang dimodifikasi, pada tahun 1931 oleh ahli seismologi Harry Wood dan Frank Neumann masih sering digunakan terutama apabila tidak terdapat peralatan seismometer yang dapat mengukur kekuatan gempabumi di tempat kejadian. 
Hubungan skala MMI dengan risiko bencana adalah semakin luas zona yang berada pada skala MMI tinggi, maka risiko yang akan dihadapi akan semakin tinggi [1].

Tabel 1. Skala intensitas gempabumi BMKG [1].

\begin{tabular}{|c|c|c|c|c|}
\hline $\begin{array}{l}\text { Skala } \\
\text { SIG } \\
\text { BMKG }\end{array}$ & $\begin{array}{l}\text { Deskripsi } \\
\text { Sederhana }\end{array}$ & Deskrispsi Rinci & $\begin{array}{l}\text { Skala } \\
\text { MMI }\end{array}$ & $\begin{array}{l}\text { PGA } \\
(\text { gal) }\end{array}$ \\
\hline I & $\begin{array}{l}\text { TIDAK } \\
\text { DIRASAKAN } \\
\text { (Not Felt) }\end{array}$ & $\begin{array}{l}\text { Tidak dirasakan atau dirasakan hanya oleh beberapa } \\
\text { orang tetapi terekam oleh alat. }\end{array}$ & I-II & $<2.9$ \\
\hline II & $\begin{array}{l}\text { DIRASAKAN } \\
\text { (Felt) }\end{array}$ & $\begin{array}{l}\text { Dirasakan oleh orang banyak tetapi tidak menimbulkan } \\
\text { kerusakan. Benda-benda ringan yang digantung } \\
\text { bergoyang dan jendela kaca bergetar. }\end{array}$ & III-V & $2.9-88$ \\
\hline III & $\begin{array}{l}\text { KERUSAKAN } \\
\text { RINGAN } \\
\text { (Slight Damage) }\end{array}$ & $\begin{array}{l}\text { Bagian non struktur bangunan mengalami kerusakan } \\
\text { ringan, seperti retak rambut pada dinding, atap bergeser } \\
\text { ke bawah dan sebagian berjatuhan. }\end{array}$ & VI & $89-167$ \\
\hline IV & $\begin{array}{l}\text { KERUSAKAN } \\
\text { SEDANG } \\
\text { (Moderate } \\
\text { Damage) }\end{array}$ & $\begin{array}{l}\text { Banyak Retakan terjadi pada dinding bangunan } \\
\text { sederhana, sebagian roboh, kaca pecah. Sebagian } \\
\text { plester dinding lepas. Hampir sebagian besar atap } \\
\text { bergeser ke bawah atau jatuh. Struktur bangunan } \\
\text { mengalami kerusakan ringan sampai sedang. }\end{array}$ & $\begin{array}{l}\text { VII- } \\
\text { VIII }\end{array}$ & $\begin{array}{l}168- \\
564\end{array}$ \\
\hline V & $\begin{array}{l}\text { KERUSAKAN } \\
\text { BERAT (Heavy } \\
\text { Damage) }\end{array}$ & $\begin{array}{l}\text { Sebagian besar dinding bangunan permanen roboh. } \\
\text { Struktur bangunan mengalami kerusakan berat. Rel } \\
\text { kereta api melengkung. }\end{array}$ & $\begin{array}{l}\text { IX- } \\
\text { XII }\end{array}$ & $>564$ \\
\hline
\end{tabular}

3. Metode Penelitian

Penelitian ini dilakukan di Balai Besar Meteorologi, Klimatologi, dan Geofisika Wilayah III Denpasar. Proses pengolahan data mengunakan software ArcGIS 10.1 dan Microsoft Exel.

\subsection{Data penelitian}

Data yang digunakan dalam penelitian adalah data sekunder yaitu data alat accelerograph tahun 20172020 dan data gempabumi di wilayah Banyuwangi dengan magnitudo ( $\mathrm{M} \geq 5$ ) dari tahun 1970-2020.

\subsection{Alur penelitian}

Langkah-langkah dalam penelitian ini dilakukan dengan tiga tahap yang terdiri dari tahap pengumpulan, pengolahan, dan interpretasi data.

\subsubsection{Pengumpulan data}

Penelitian ini dimulai dari pengumpulan data gempabumi yang sudah tercatat pada alat accelerograph stasiun JAGI BMKG Banyuwangi. Terdapat sebanyak 86 peristiwa gempabumi di sekitar wilayah Banyuwangi yang tercatat dari tahun 2017-2020. Data ini merupakan data acuan untuk menentukan metode atau rumus empiris yang sesuai untuk diterapkan di wilayah Banyuwangi. Pengumpulan data selanjutnya yaitu pengumpulan data gempabumi dari website International Seismological Center (ISC) dari tahun 1970-2020 yang banyaknya sekitar 656 peristiwa gempabumi terekam dengan koordinat 112,061 sampai 115,62 BT dan -11,35 sampai -5,878 LS.

\subsubsection{Pengolahan data}

Setelah proses pengumpulan data dilakukan, selanjutnya adalah proses pengolahan data gempabumi yang sudah tercatat di alat accelerograph stasiun BMKG. Proses yang pertama yaitu pada data ini akan dilakukan perhitungan PGA dengan menggunakan lima rumus empiris yaitu Mc Guirre, Donovan, Fukushima dan Tanaka, Setiawan dan Esteva. Parameter yang digunakan yaitu posisi gempabumi (lintang dan bujur), jarak hiposenter, kedalaman gempabumi, dan magnitudo gempabumi. Selanjutnya nilai PGA alat accelerograph dan nilai PGA setiap perhitungan rumus empiris akan dilakukan perhitungan nilai RMS (Root Mean Square). Perhitungan nilai ini dilakukan dengan menggunakan perangkat lunak Microsoft Excel. Untuk menentukan rumus empiris yang sesuai di wilayah Banyuwangi, akan dipilih rumus empiris yang memiliki nilai RMS paling kecil. Selanjutnya yaitu membuat titik-titik grid pada wilayah Banyuwangi dengan jarak antar titik satu dengan titik lainya yaitu sebesar 0,125 atau 
13,875 kilometer. Titik-titik grid ini merupakan titik pengamatan untuk menghitung nilai PGA di wilayah Banyuwangi.

Setelah membuat dan mendapatkan titik pengamatanya, maka langkah selanjutnya menghitung nilai PGA pada setiap titik menggunakan data gempabumi website ISC dari tahun 1970-2020 dengan perangkat lunak Microsoft Excel dan rumus empiris terpilih (rumus Setiawan). Dari hasil pengolahan data diperoleh nilai percepatan getaran tanah maksimum yang berbeda-beda untuk setiap titik pengamatanya. Selanjutnya adalah membuat peta sebaran percepatan getaran tanah maksimum dan peta tingkat bahaya bencana gempabumi di wilayah Banyuwangi menggunakan software ArcGis10.1 berdasarkan nilai PGA yang sudah didapat. Selanjutnya diperoleh peta percepatan getaran tanah maksimum dan peta tingkat bahaya bencana gempabumi di wilayah Banyuwangi. Terdapat warna kontur pada peta yang membedakan nilai PGA dan peta tingkat bahaya bencana gempabumi.

\subsubsection{Intrepretasi data}

Dalam tahapan interpretasi data, akan dilakukan interpretasi peta nilai percepatan getaran tanah maksimum dan peta tingkat bahaya bencana gempabumi di wilayah Banyuwangi. Dari hasil interpretasi dapat diketahui daerah yang memiliki nilai PGA dari terendah sampai tertinggi. Serta mengetahui daerah atau kecamatan mana yang memiliki tingkat bahaya bencana gempabumi paling tinggi.

\section{Hasil Dan Pembahasan}

\subsection{Pemilihan rumus empiris}

Data yang digunakan adalah data gempabumi alat accelerograph tahun 2017-2020 sebanyak 86 peristiwa gempabumi. Dengan parameter yang digunakan yaitu episenter (bujur dan lintang), jarak hiposenter, kedalaman dan magnitudo gempabumi. Berdasarkan hasil yang direproleh dipilih rumus empiris dengan RMS paling kecil. Nilai RMS dapat dilihat pada Tabel 2 menunjukan bahwa rumus Setiawan memiliki nilai RMS paling kecil, maka nilai PGA rumus Setiawan paling mendekati dengan nilai PGA alat accelerograph. Rumus empiris tersebut akan digunakan untuk menghitung nilai dan pembuatan kontur PGA dalam penelitian ini.

Tabel 2. Nilai RMS setiap rumus empiris.

\begin{tabular}{lccccc}
\hline $\begin{array}{l}\text { Rumus } \\
\text { Empiris }\end{array}$ & Mc. Guirre & Esteva & Donovan & $\begin{array}{l}\text { Fukhusima } \\
\text { dan Tanaka }\end{array}$ & Setiawan \\
\hline Nilai RMS & 1,282 & 0,652 & 1,433 & 0,540 & 0,382 \\
\hline
\end{tabular}

4.2 Identifikasi tingkat bahaya bencana gempabumi

Untuk mendapatkan peta kontur tingkat bahaya bencana gempabumi di wilayah Banyuwangi. Dalam penelitian ini digunakan data historis gempabumi di wilayah Banyuwangi dari tahun 1970-2020 ISC dengan magnitudo $\geq 5$, didapat sebanyak 656 peristiwa gempabumi. Data gempabumi yang dipilih selanjutnya dihitung nilai PGA maksimum dengan menggunakan rumus empiris Setiawan. Selanjutnya dibuat peta kontur PGA maksimum untuk wilayah Banyuwangi menggunakan software ArcGIS 10.1. Peta kontur PGA maksimum untuk wilayah Banyuwangi hasil software ArcGis 10.1 dapat dilihat pada Gambar 2.

Dapat diketahui bahwa wilayah Banyuwangi sebelah timur memiliki nilai percepatan getaran tanah maksimum tertinggi dengan warna kontur merah sebesar 212,270-301,801 gal. Sedangkan wilayah Banyuwangi sebelah barat memiliki nilai percepatan getaran tanah maksimum terendah dengan warna kontur kuning sebesar 88,433-118,555 gal. Dan wilayah Banyuwangi sebelah selatan memiliki nilai percepatan getaran tanah maksimum sebesar 141,147-169,596 gal dengan warna kontur oranye. Ada beberapa faktor yang mempengaruhi besar kecilnya nilai percepatan getaran tanah maksimum di wilayah Bayuwangi, yaitu posisi gempabumi, kedalaman gempabumi, magnitudo gempabumi, jarak hiposenter gempabumi, serta wilayah Banyuwangi sebelah timur yang berdekatan dengan zona flores backarc thrust dapat menyebabkan banyak terjadinya gempabumi di sebelah timur Banyuwangi di bandingkan dengan wilayah Banyuwangi sebelah barat.

Berdasarkan hasil nilai PGA pengolaan data dari histori gempabumi tahun 1970-2020, dibuat peta tingkat bahaya bencana gempabumi menggunakan software ArcGIS 10.1 dapat dilihat pada Gambar 3. 


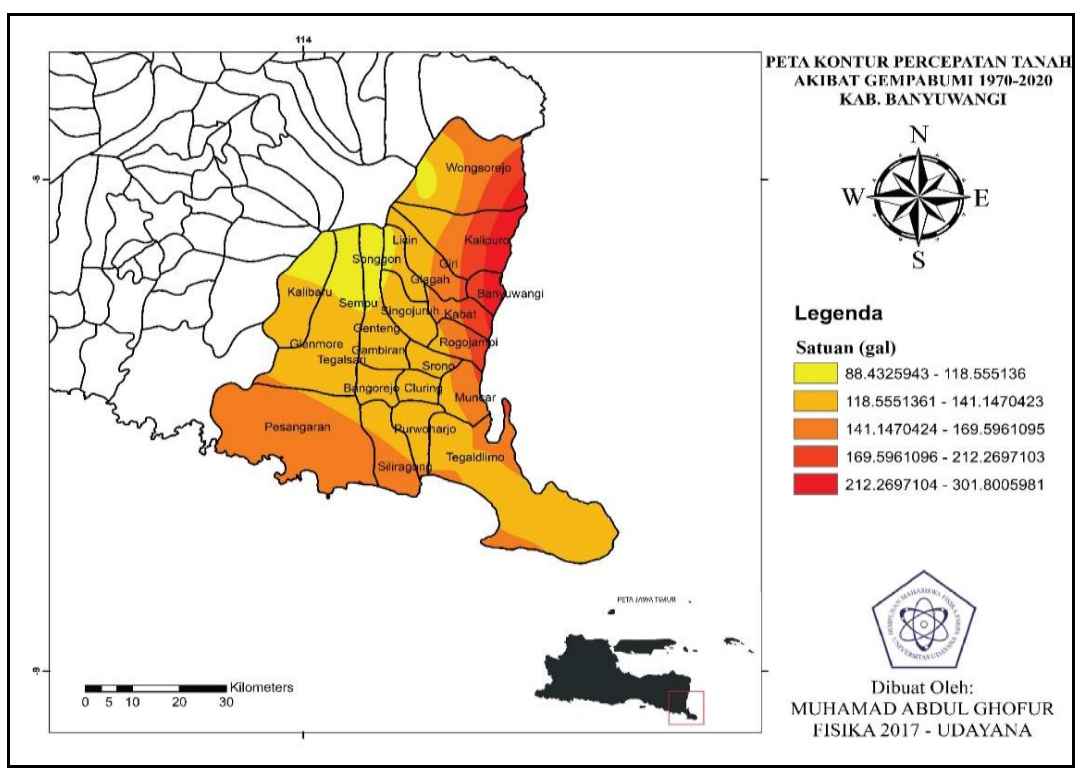

Gambar 2. Peta kontur percepatan getaran tanah maksimum Kabupaten Banyuwangi.

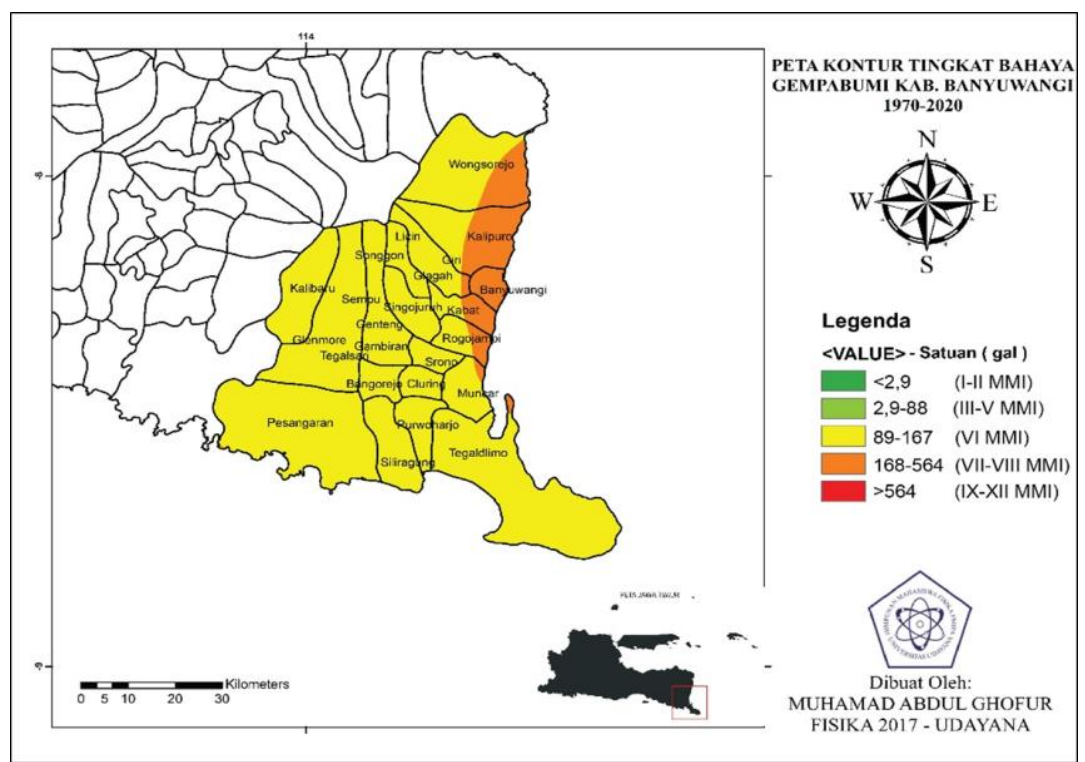

Gambar 3. Peta tingkat bahaya bencana gempabumi Kabupaten Banyuwangi.

Dapat diketahui untuk tingkat bahaya bencana gempabumi sebagian besar didonimasi dengan skala intensitas VI MMI, artinya bagian non struktur bangunan mengalami kerusakan ringan, seperti retak rambut pada dinding, atap bergeser ke bawah berada pada wilayah Banyuwangi sebelah barat, Wilayah ini mencangkup Kecamatan Licin, Kecamatan Giri, Kecamatan Songgon, Kecamatan Glagah, Kecamatan Kalibaru, Kecamatan Sempu, Kecamatan Singonjuruh, Kecamatan Genteng, Kecamatan Gambiran, Kecamatan Glemore, Kecamatan Tegalsari, Kecamatan Srono, Kecamatan Muncar, Kecamatan Cluring, Kecamatan Bangorejo, Kecamatan Pesanggran, Kecamatan Siliragung, Kecamatan Purwoharjo, dan Kecamatan Tegaldlimo. Untuk tingkat bahaya bencana gempabumi paling tinggi berada di wilayah Banyuwangi sebelah timur termasuk dalam skala VII-VIII MMI, artinya sebagian berjatuhan dan banyak retakan terjadi pada dinding bangunan sederhana, sebagian roboh, kaca pecah, sebagian plester dinding lepas, hampir sebagian besar atap bergeser ke bawah atau jatuh, struktur bangunan mengalami kerusakan ringan sampai sedang. Wilayah ini mencangkup Kecamatan Wongsorejo, Kecamatan Kalipuro, Kecamatan Banyuwangi, Kecamatan Kabat, dan Kecamatan Rogojampi. Hal ini sesuai dengan hasil analisa yang telah dilakukan dimana nilai percepatan getaran tanah maksimum tertinggi untuk wilayah Banyuwangi sebesar 301,801 gal. 


\section{Kesimpulan}

Berdasarkan pada hasil perhitungan RMS dari kelima rumus empiris, bahwa rumus Setiawan empiris paling sesuai diterapkan di wilayah Banyuwangi. Dan untuk tingkat bahaya bencana gempabumi wilayah Banyuwangi didonimasi dengan skala intensitas VI MMI, sedangkan tingkat bahaya bencana gempabumi paling tinggi berada di wilayah Banyuwangi bagian timur termasuk dalam skala VII-VIII MMI dengan nilai percepatan getaran tanah maksimum tertinggi yaitu 301,801 gal.

\section{Ucapan Terima Kasih}

Penulis menyampaikan terimakasih kepada BMKG Wilayah III Denpasar yang telah memberikan bantuan fasilitas dalam penelitian ini. Serta staf dosen bidang minat Fisika Bumi, Prodi Fisika, FMIPA, UNUD yang telah memberikan saran serta masukan terkait penelitian ini.

\section{Pustaka}

[1] BMKG, Gempabumi, 2021. http://balai3.denpasar.bmkg.go.id/tentang-gempa, Diakses 15 Januari 2021.

[2] Yeza Febriani, Ika Daruwati, Rindi Genesa Hatika, Analisis Nilai Peak Ground Acceleration Dan Indeks Kerentanan Seismik Berdasarkan Data Mikroseismik Pada Daerah Rawan Gempabumi Di Kota Bengkulu. Jurnal Ilmiah Edu Research, 2013, Vol. 2, No.2, pp. 85-90.

[3] Urip Setiyono, Indra Gunawan, Priyobudi, Tatok Yatimantoro, Rudi Teguh Imananta, Mohamad Ramadhan, Hidayati, Septa Anggraini, Resty Herdiani Rahayu, Purnomo Hawati, Debi Safari Yogaswara, Admiral Musa Julius, Mila Apriani, Muhamad Harvan, Gloria Simangunsong, Tribowo Kriswinarso, Katalog Gempabumi Signifikan dan Merusak 1821-2018, Pusat Gempabumi dan Tsunami Kedeputian Bidang Geofisika Badan Meteorologi Klimatologi dan Geofisika, Jakarta, 2019.

[4] Cloudya Gabriella Kapojos, Gerald Tamuntuan, Guntur Pasau, Analisis Percepatan Tanah Maksimum Dengan Menggunakan Rumusan Esteva Dan Donovan, Jurnal Ilmiah Sains, 2015, Vol. 15, No. 2, pp. 99-104.

[5] Dinas Kependudukan dan Pencatatan Sipil Kabupaten Banyuwangi, Kabupaten Banyuwangi, 2021. https://www.banyuwangikab.go.id/profil/kependudukan-dannaker.html, Diakses 15 Januari 2021.

[6] Google Map, Peta Kabupaten 2021. https://www.google.com/maps/place/Kabupaten+Banyuwangi,+Jawa+Timur/@, Diakses 8 Januari 2021.

[7] Gunawan Ibrahim dan Subardjo, Gempabumi, Badan Meteorologi dan Geofisika, Jakarta, 2010.

[8] Meita Aulia Sari, Pemetaan Percepatan Getaran Tanah Maksimum Dan Intensitas Gempabumi Di Kawasan Jalur Sesar Sungai Oyo Yogyakarta, Skripsi, Program Studi Fisika FMIPA UNY, 2016.

[9] I Putu Arix Putra Wiguna, dan I made Yuliara, Penentuan Persamaan Empiris Percepatan Tanah Di Wilayah Bali Berdasarkan Data Gempabumi Periode 2008-2016, Koppa Journal Program Studi Pendidikan Fisika FMIPA Universitas Hamzanwali, 2019, Vol. 3, No. 2, pp. 71-28.

[10] I Ketut Sukarasa dan Ni Luh Putu Trisnawati, Analisa Gempabumi Dengan Menggunakan Data Percepatan Getaran Tanah (Studi Kasus Gempabumi NTB Tanggal 1 Agustus 2016), Program Studi Fisika FMIPA UNUD, Jimbaran, 2017.

[11] Muhammad Syifa'uddin, Emetaan Tingkat Resiko Kerusakan Akibat Gempabumi Di Sekitar Sesar Palu Koro Berdasarkan Pola Percepatan Tanah Maksimum Dengan Metode Mc. Guirre R.K, Skripsi, Universitas Islam Negeri Maulana Malik Ibrahim, 2017.

[12] Rudy Darsono, Analisa Tingkat Risiko Bencana Gempabumi Di Wilayah Bali, Skripsi, Program Studi Fisika FMIPA Universitas Udayana, Jimbaran, 2014. 